\title{
COST SYSTEMS PENDEKATAN ACTIVITY BASED COSTING: STUDI KASUS USAHA TEMBAKAU VIRGINIA LOMBOK
}

\author{
Widia Astuti \\ Universitas Mataram \\ widiaastutiakuntansi@unram.ac.id \\ Animah \\ Universitas Mataram \\ animahmtr@unram.ac.id \\ Diterima : 6 Mei 2020 \\ Direview : 19 Mei 2020 \\ Diterima : 5 Juni 2020
}

\begin{abstract}
Lombok has an excellent agricultural commodity, Virginia tobacco. Tobacco production capacity in Lombok is able to meet $80 \%$ of national needs. Anomalous weather, the amount of harvest and the purchase price by the cigarette company the previous year resulted in fluctuations in the purchase price. Often farmers suffer losses due to lack of information mainly because there is no recording of production costs. The research objective is to describe the production cost system of $A B C$ approach as a material for decision making. Research location in Sakra District, East Lombok. Acquisition of research data is done by interview and observation. The results showed that in batch 1 and 2 processing, tobacco drying entrepreneurs experienced losses. Entrepreneurs experience profits after batch 3 processing and so on. In the aggregate, the tobacco drying business provides economic benefits for the citizens of Lombok.
\end{abstract}

Keywords: Cost Systems, ABC, Tobacco Virginia Lombok

\begin{abstract}
Abstrak
Lombok memiliki komoditas unggulan pertanian yaitu tembakau jenis Virginia. Kapasitas produksi tembakau di Lombok mampu memenuhi $80 \%$ kebutuhan nasional. Anomali cuaca, jumlah hasil panen dan harga beli oleh perusahaan rokok tahun sebelumnya mengakibatkan fluktuasi harga beli. Seringkali petani mengalami kerugian karena kekurangan informasi terutama disebabkan karena tidak ada pencatatan biaya produksi. Tujuan penelitian untuk mendeskripsi sistem biaya produksi pendekatan $A B C$ sebagai bahan pengambilan keputusan. Lokasi penelitian di Kecamatan
\end{abstract}


Sakra, Lombok Timur. Perolehan data penelitian dilakukan dengan wawancara dan observasi. Hasil penelitian menunjukkan bahwa pada pemrosesan batch 1 dan 2, pengusaha pengeringan tembakau mengalami kerugian. Pengusaha mengalami keuntungan setelah pemrosesan batch 3 dan seterusnya. Secara agregat, usaha pengeringan tembakau memberikan manfaat ekonomi bagi warga Lombok.

Kata kunci: Sistem Biaya, ABC, Tembakau Virginia Lombok

\section{PENDAHULUAN}

Tembakau Virginia Lombok merupakan komoditas yang memberikan pengaruh signifikan bagi perekonomian NTB. Pengembangan Tembakau jenis Virginia sangat sesuai dengan karakteristik tanah yang ada di Lombok. Hasil produksi tembakau Virginia Lombok mencapai 59.500 ton dan memenuhi 80\% kebutuhan nasional (distan.lomboktimurkab.go.id). Tembakau Virginia disebut juga dengan flue-cured Virginia (FCV) karena proses produksi dengan memanfaatkan aliran udara panas untuk proses pengeringan. Tembakau menuai kontroversi karena dianggap sebagai perusak kesehatan namun memiliki kontribusi besar bagi perekonomian.

Komoditas tembakau mampu menyiapkan 400 hari kerja orang (HKO)/hektar, dari proses pembibitan, pengolahan hingga penjualan. Dana bagi hasil cukai hasil tembakau ( $\mathrm{DBH}-\mathrm{CHT}$ ) sesuai Peraturan Menteri Keuangan No 12, NTB sebagai daerah penghasil tembakau mendapatkan Rp. 295.658.410. DBH-CHT dialokasikan ke Pemprov NTB Rp. 88,6 M, Pemkab Bima Rp. 9,7 M, Pemkab Dompu Rp. 5,2 M, Pemkab Lombok Barat Rp. 15,5 M, Pemkab Loteng Rp. 48,2 M. Pemkab Lotim Rp. 54,3 M, Pemkab Sumbawa Rp. 9,3 M, Pemkot Mataram Rp. 49,8 M, Pemkot Bima 2 M, Pemkab Sumbawa Barat Rp. 3 M, dan Pemkab Lombok Utara Rp, 9,4 M (https://investasiperizinan.ntbprov.go.id).

Potensi besar mengakibatkan banyak petani yang beralih menanam tembakau, sehingga produksi melebihi kapasitas penyerapan oleh perusahaan pembeli. Kelebihan produksi memengaruhi harga jual tembakau menjadi lebih 
rendah, hal ini membuat petani dan pengusaha pengeringan tembakau menjadi rugi. Faktor anomali cuaca mengakibatkan kualitas produk berkurang. Teknik produksi sangat memengaruhi kualitas produk. Masalah ini mengakibatkan kerugian dan konflik antara petani, pengusaha pengeringan dan perusahaan pembeli.

Selama ini, petani dan pengusaha pengeringan tembakau tidak pernah melakukan perhitungan dalam produksi. Mereka berproduksi sesuai kebiasaan tanpa mengetahui harga jual dari produknya. Pemerintah sesuai Perda berperan dalam mediasi harga beli dan kuota jumlah pembelian antara perusahaan pembeli dan petani/pengusaha pengeringan. Namun pada praktiknya, perusahaan menentukan sendiri harga beli produk tembakau kering (https://dutaselaparang.com). Perhitungan harga pokok produksi sangat berguna untuk antisipasi kerugian karena fluktuasi harga. Penelitian ini akan melakukan perhitungan harga pokok produksi menggunakan pendekatan Activity Based Costing ( $A B C)$. Unit analisis dilakukan pada pengusaha pengeringan tembakau.

Tujuan penelitian untuk mendeskripsi harga pokok produk dan tingkat profitabilitas usaha tembakau Virginia di Lombok menggunakan pendekatan ABC. Kontribusi penelitian bermanfaat untuk memberikan gambaran sederhana penerapan $A B C$ pada jenis usaha padat karya. Hasil penelitian dapat menjadi pertimbangan pengambilan keputusan bagi pengusaha, pemerintah dan perusahaan mitra.

\section{TELAAH LITERATUR}

\section{Activity-Based Costing}

Cost system merupakan faktor yang memiliki peranan penting dalam bisnis. Sistem perhitungan biaya pokok produksi berfungsi sebagai dasar 
penentuan harga jual dan bagian dari strategi perusahaan untuk memilih market share. Sistem pembebanan biaya mengalami perkembangan dari tradisional sampai kontemporer seperti $A B C$ dan Target Costing. Sistem biaya tradisional menggunakan alokasi berdasarkan volume, jadi semua biaya produksi akan dibebankan pada semua produk secara merata (Haque, 2006). Penelitian ini akan menggunakan sistem pembebanan biaya menggunakan $\mathrm{ABC}$.

$A B C$ menyediakan kerangka kerja konseptual untuk mengaitkan aspek keuangan, produksi, penjadwalan, pemesanan, pemasaran dan data penjualan yang bersumber dari catatan selama proses produksi (Kaplan, 2009). ABC bermanfaat untuk menentukan alokasi biaya yang lebih akurat dan menganalisis produk yang paling menguntungkan pada perusahaan yang memiliki produk beragam. Selain itu, $A B C$ bermanfaat untuk melakukan customer analisis yaitu analisis untuk menemukan pelanggan yang paling menguntungkan. Selama ini ABC lebih banyak diterapkan pada perusahaan pemanufakturan karena perusahaan jenis ini memiliki sistem, aplikasi dan data produksi yang lengkap. Namun prinsip dasar $A B C$ adalah pembebanan biaya harus berdasarkan konsumsi jam kerja dan sumberdaya yang akurat untuk setiap produk atau fase produksi.

Perkembangan terbaru $A B C$ yang dikutip dari Kaplan (2009) dikenal dengan Time Driven Activity Based Costing (TDABC). Model TDABC lebih sederhana dan akurat dalam perhitungan biaya karena menggunakan dua parameter untuk melakukan estimasi yaitu:

1. Tingkat biaya untuk menyediakan kapasitas sumberdaya, dan

2. Kapasitas sumberdaya yang dikonsumsi (biasanya bentuk unit waktu) dari setiap kinerja aktivitas dan sumberdaya untuk produksi barang dan jasa. 
Poin penting ketika entitas ingin menerapkan perhitungn biaya dengan pendekatan $A B C$ adalah harus mengurai proses produksi suatu barang atau jasa. Setiap tahapan dalam proses produksi harus dilakukan pengamatan. Selanjutnya dilakukan identifikasi sumberdaya dan jam kerja pelaksanaan tugas disetiap proses produksi. Langkah terakhir dengan melakukan perhitungan nilai moneter sehingga dapat dijumlahkan menjadi harga pokok produksi. Jadi ketika penelusuran terhadap semua aktivitas produksi pada produk yang beragam, kita dapat menentukan jenis produk dan kelompok pelanggan yang paling menguntungkan.

\section{Tembakau Virginia Lombok}

Tembakau dalam bahasa Latin termasuk spesies Nicotiana tabacum $L$ merupakan tanaman berakar tunggang dengan batang berbentuk lurus. Setiap ruas batang ditumbuhi daun yang berbentuk oval atau bulat tergantung varietasnya, memiliki jumlah daun dalam satu tanaman mencapai 28-32 helai (distan.lomboktimurkab.go.id).

Tembakau Virginia merupakan salah satu varietas tembakau yang tumbuh subur di Lombok, tersebar di Lombok Timur sebanyak $70 \%$, sisanya ada di Lombok Tengah. Jenis tembakau ini mulai dikembangkan di Lombok sejak tahun 1969 yang dirintis oleh PT Faroka, PT BAT tahun 1971, berikutnya PT XXVII dan NV GIEB tahun 1974. Kemudian PT Djarum 1980 dan PT Anugerah Alam Abadi, PT Mangli Jaya Raya, PT Cakrawala tahun 1987. Mengikuti ditahun berikutnya PT Tresno Bentoel, PT Trisno Adi, PT HM Sampoerna, PT Sadhana Arifnusa, PT Gelora Jaya dan UD Nyoto Permadi (distan.lomboktimurkab.go.id).

Beberapa perusahaan yang melakukan pembelian diantaranya melakukan pembinaan kepada petani: PT IDS, PT Trisno Adi, PT Sadhana, UD Jawara, CV Kalimas KJ, CV Karya BS, PT Bentoel, PT Djarum, PT Budi JS dan 
PT AOI. Sementara itu perusahaan yang melakukan pembelian tanpa melakukan pembinaan antara lain: UD Nyoto Permadi, UD Uswanto, UD Supianto, UD Rinjani MB, UD Bintang Mas, UD Sumber Rezeki dan KUD Tunggal Kayun (https://investasi-perizinan.ntbprov.go.id).

Hasil panen daun tembakau di lansir dari website Dinas Pertanian Lombok Timur, terbagi menjadi tiga tahap. Kriteria panen berdasarkan tanda kematangan daun di pohon sebagai berikut: daun bawah (1-4 lembar) warna daun hijau dan batang daun putih. Daun tengah (5-25 lembar) berwarna kuning kenanga dan daun atas (26-32 lembar). Tingkatan daun dihitung dari jarak terdekat dengan tanah sampai daun di pucuk pohon. Namun untuk satu kali proses produksi pengeringan tembakau, umumnya dilakukan dengan memetik 3 atau 4 lembar daun. Di mulai dari daun paling bawah sampai pucuk.

Kualitas hasil produksi akan berbeda yang disebabkan oleh karakteristik daun yang akan menghasilkan perbedaan warna, ketebalan dan ukuran. Daun paling bawah berwarna hitam, pendek dan tipis. Produk ini memiliki harga jual paling rendah. Frekuensi proses produksi untuk daun ini menjadi 2 batch. Pada batch ketiga sampai 7 hasil produksi memiliki ciri warna kuning keemasan, tebal dan panjang. Produk ini memiliki harga yang cukup bagus. Terakhir terdiri dari 2 batch memiliki hasil produksi dengan ciri warna keemasan, tebal dan lebih pendek dari sebelumnya.

Rantai nilai pengolahan tembakau berbentuk kerjasama antara petani dengan perusahaan mitra. Namun ada juga petani yang hanya melakukan penanaman dan menjual produk daun kepada pengusaha pengeringan tembakau. Biasanya dilakukan oleh petani tembakau dari wilayah Lombok Tengah. Sistem pembelian dari pengusaha pengeringan tembakau berdasarkan kontrak, jadi semua hasil produksi daun dari daun bawah sampai atas harus di beli semua. Penetapan harga jual daun tembakau ini berdasarkan harga pasar. Selain itu ada kelompok petani sekaligus sebagai pengusaha yang langsung melakukan proses pengeringan sendiri. 
Setelah produk tembakau kering dihasilkan, akan dilakukan penjualan kepada perusahaan mitra. Penetapan harga beli oleh perusahaan mitra berbeda-beda sesuai dengan kualitas produk yang di inginkan perusahaan mitra. Petani sekaligus pengusaha yang melakukan proses pengeringan sendiri, harus menjual produknya kepada perusahaan mitra, jika tidak maka perusahaan mitra akan memberikan sangsi dengan tidak membeli produknya.

Selain itu penentuan harga pembelian oleh perusahaan dipengaruhi oleh ketersediaan produk. Sesuai hukum ekonomi, semakin banyak penawaran maka harga akan turun. Produksi daun tembakau cukup rentan terhadap cuaca, faktor curah hujan maupun anomali cuaca akan memengaruhi jumlah dan kualitas produksi daun. Disamping itu, masalah yang paling sering terjadi pada komoditas pertanian adalah, ketika harga cukup tinggi, maka periode berikutnya banyak yang menanam tembakau. Sehingga akan terjadi kelebihan produksi, begitu terus berlaku sebaliknya. Hal ini sangat merugikan pihak pengusaha karena produknya tidak laku terjual sedangkan produk ini tidak dapat disimpan.

Selain itu, ada juga pembeli produk tembakau atau tengkulak yang membeli tembakau kering secara borongan tanpa disortir berdasarkan grade. Posisi tawar pengusaha tembakau dapat dikatakan terlalu lemah, karena ketika membeli daun basah harga ditetapkan oleh petani. Begitu juga ketika perusahaan akan menjual produk, penentu harga adalah pembeli baik tengkulak ataupun perusahaan mitra.

Biaya tenaga kerja untuk proses produksi ditentukan oleh harga pasar, persaingan dalam merekrut tenaga kerja mengakibatkan beban tenaga kerja menjadi tinggi. Karena usaha ini berupa usaha padat karya, biaya tenaga kerja berjumlah signifikan. Penelitian ini akan melakukan identifikasi biaya produksi usaha pengeringan tembakau dengan pendekatan $A B C$. Indikator biaya produksi di kelompokkan berdasarkan fungsi dalam proses produksi. Selama 
ini belum ada penelitian yang melakukan analisis harga pokok produksi pada usaha pengeringan tembakau Virginia Lombok.

\section{METODE PENELITIAN}

Penelitian ini merupakan studi deskripsi yang menganalisis cost systems usaha tembakau Virginia Lombok. Pengumpulan data diperoleh melalui wawancara dan observasi. Populasi penelitian meliputi semua pengusaha tembakau di Lombok. Teknik pengambilan sampel menggunakan metode convenience. Sampel penelitian ini adalah petani dan pengusaha pengeringan tembakau yang ada di Dusun Kuang Derek dan Dasan Baru Kecamatan Sakra Pusat. Data penelitian dapat digeneralisir karena populasi memiliki parameter data yang sama.

Analisis cost systems pendekatan activity based costing dilakukan dalam dua tahap. Tahap pertama adalah melakukan penelusuran aktivitas selama proses produksi. Berikutnya peneliti mencari informasi biaya di setiap proses produksi.

\section{HASIL PENELITIAN DAN PEMBAHASAN}

Uraian hasil penelitian cost systems pendekatan $A B C$ pada proses produksi tembakau kering sebagai berikut. Tahap pertama, penelusuran aktivitas proses produksi tembakau kering. Proses produksi tembakau kering terdiri dari tiga kelompok aktivitas yaitu tahap persiapan meliputi pengikatan daun tembakau pada kayu menggunakan tali agar bisa diatur dalam rak-rak yang ada di dalam oven. Kegiatan ini memakan waktu selama satu hari. Jadi biaya yang dikeluarkan selama proses ini merupakan biaya untuk satu hari.

Kemudian dilanjutkan dengan proses pengeringan selama 5 hari. Selama proses pengeringan terdapat dua tenaga kerja yang bertugas untuk 
menjaga kestabilan suhu oven dengan mengatur bahan bakar yang dimasukkan dalam tungku. Proses ini memerlukan kecermatan dan keahlian yang baik, karena pengaturan suhu akan memengaruhi kualitas hasil pengeringan.

Proses terakhir adalah persiapan pengemasan tembakau kering menggunakan mesin pressed. Sebelumnya tembakau sudah dilepas dari tali kemudian disortir sesuai grade. Indikator penentuan grade menggunakan warna, ukuran dan ketebalan. Hasil panen daun tembakau, memiliki karakteristik yang berbeda karena tingkat ukuran dan ketebalan daun. Jadi daun yang lebih dekat dengan tanah akan lebih ringan dibanding daun yang lebih jauh dari tanah.

Proses produksi yang bertujuan untuk pengeringan akan menghasilkan daun tembakau kering mencapai berat 5\%, 15\% dan $18 \%$ dari daun segar. Rincian aktivitas dan pemakaian sumberdaya di setiap 1 (satu) batch proses produksi daun tembakau kering diuraikan di tabel 1 identifikasi biaya produksi.

Tabel 1

Identifikasi Proses Produksi

\begin{tabular}{|c|c|}
\hline Proses Produksi & Indikator \\
\hline \multirow[t]{6}{*}{ Aktivitas Persiapan } & Harga tembakau \\
\hline & Biaya angkut pembelian \\
\hline & Biaya tenaga kerja untuk proses mengikat \\
\hline & Biaya tenaga kerja untuk mengatur pada rak oven \\
\hline & Biaya tenaga kerja tetap \\
\hline & Bahan habis pakai \\
\hline \multirow[t]{3}{*}{ Aktivitas Pengeringan } & Biaya bahan bakar \\
\hline & Biaya depresiasi/sewa oven \\
\hline & Biaya tenaga kerja tetap \\
\hline \multirow[t]{2}{*}{ Aktivitas Pengemasan } & Biaya tenaga kerja untuk menurunkan dari rak oven \\
\hline & Biaya tenaga kerja untuk melepas tali \\
\hline
\end{tabular}


Biaya tenaga kerja untuk proses sortir

Biaya tenaga kerja untuk proses pressed

Biaya tenaga kerja tetap

Biaya bahan habis pakai

Beban angkut penjualan

Setiap 1 batch produksi memerlukan jumlah jam tenaga kerja dalam jumlah yang cukup besar karena industri ini termasuk usaha padat karya. Pada awal usaha ini berkembang, perhitungan biaya tenaga kerja berdasarkan sistem penggajian. Namun sejak semakin banyak usaha sejenis, terjadi persaingan dalam merekrut pekerja.

Sistem yang ditawarkan adalah sistem bayar harian per tenaga kerja. Perkembangan terakhir, upaya merekrut tenaga kerja dilakukan dengan sistem borongan kelompok pekerja. Jadi setiap proses produksi di bayar secara langsung dengan harga yang sudah disepakati sebelumnya.

Biaya tenaga kerja yang tercantum dalam perhitungan merupakan biaya setiap tahapan produksi, terlepas dari jumlah personel pekerja. Biaya-biaya ini hampir seragam disetiap sentra industri pengeringan tembakau. Selain pekerja lepas, usaha ini membutuhkan minimal 2 tenaga kerja tetap. Setelah dihitung tarif perhari termasuk insentif rokok mencapai Rp 50.000 perorang.

Jumlah daun segar yang akan dikeringkan adalah 4 ton dengan harga Rp 230.000/kw. Bahan bakar yang digunakan berupa kayu bakar, setiap proses pembakaran membutuhkan sekitar $2 / 3$ truk dengan harga $R p$ 1.700.000 termasuk ongkos kirim. Bahan habis pakai untuk makanan dan keperluan lain bernilai Rp 200.000/hari. Selain itu terdapat biaya sewa untuk oven bagi yang tidak punya oven. Perhitungan ini berdasarkan pendekatan biaya jadi menggunakan biaya sewa bukan biaya depresiasi. Total biaya yang diperlukan untuk setiap proses pengeringan $\mathrm{Rp}$ 15.415.000, rincian biaya dapat dilihat di tabel biaya produksi. 


\section{Tabel 2}

Biaya Produksi

\begin{tabular}{llr}
\hline \multicolumn{1}{c}{ Indikator } & & \multicolumn{1}{c}{ Total } \\
\hline Harga tembakau & $\mathrm{Rp}$ & 9.200 .000 \\
Biaya angkut pembelian & $\mathrm{Rp}$ & 500.000 \\
Biaya tenaga kerja proses mengikat & $\mathrm{Rp}$ & 400.000 \\
Biaya tenaga kerja mengatur di rak oven & $\mathrm{Rp}$ & 240.000 \\
Biaya tenaga kerja tetap & $\mathrm{Rp}$ & 100.000 \\
Bahan habis pakai & $\mathrm{Rp}$ & 200.000 \\
Biaya bahan bakar & $\mathrm{Rp}$ & 1.700 .000 \\
Biaya sewa oven & $\mathrm{Rp}$ & 500.000 \\
Biaya tenaga kerja tetap & $\mathrm{Rp}$ & 350.000 \\
Biaya tenaga kerja menurunkan dari rak oven & $\mathrm{Rp}$ & 150.000 \\
Biaya tenaga kerja melepas tali & $\mathrm{Rp}$ & 300.000 \\
Biaya tenaga kerja proses sortir & $\mathrm{Rp}$ & 400.000 \\
Biaya sewa mesin pressed & $\mathrm{Rp}$ & 150.000 \\
Biaya tenaga kerja untuk proses pressed & $\mathrm{Rp}$ & 400.000 \\
Biaya tenaga kerja tetap & $\mathrm{Rp}$ & 100.000 \\
Biaya bahan habis pakai & $\mathrm{Rp}$ & 200.000 \\
Biaya angkut penjualan & $\mathrm{Rp}$ & 125.000 \\
Jumlah biaya produksi untuk 1 batch & $\mathrm{Rp}$ & 15.015 .000 \\
\hline
\end{tabular}

Biaya produksi batch 1 dan 2 sebesar Rp 15.015.000, hasil produksi mencapai $5 \%$ dari berat daun basah. Jadi dari 4 ton akan menghasilkan $2 \mathrm{kw}$ daun kering. Harga jual Rp 2.000.000/kw, jumlah penjualan menjadi Rp 4.000.000. Pengusaha mengakali selisih biaya produksi yang cukup besar dengan memotong rantai produksi sampai proses melepas tali. Penghematan biaya mencapai Rp 1.375.000. Jadi jika sebelumnya selisih Rp 11.015 .000 menjadi Rp 9.340.000. Sistem pembelian kontrak semua hasil produksi 
ataupun penanaman sendiri tidak memungkinkan bagi pengusaha untuk mengabaikan produksi batch 1 ini. Beberapa pengusaha memakai alternative pengeringan menggunakan panas matahari dalam memroses daun bawah tembakau. Harga jual produk kering matahari berkisar Rp 1.500.000/kw. Walaupun masih rugi tapi nilai kerugian tidak besar karena telah menghemat biaya produksi.

Produksi batch 3 sampai seterusnya (12) terdapat perbedaan untuk biaya tenaga kerja bagian pressed karena biaya berdasarkan berat daun. Jika sebelumnya hasil produksi mencapai $5 \%$, saat ini hasil produksi mencapai kadar $15 \%$ jadi biaya sebelumnya Rp 400.000 mengalami kenaikan menjadi Rp 1.200.000. Total biaya produksi menjadi Rp 15.815.000.

Harga jual produk berbeda dengan sebelumnya karena tahap ini menghasilkan produk dengan kualitas terbaik, warna kuning keemasan, panjang dan tebal. Harga jual menjadi Rp 4.000.000/kw. Jumlah hasil produksi menjadi 6 kw. Penjualan mencapai Rp 24.000.000, keuntungan yang diperoleh sebesar Rp 8.185.000. Pada tahap ini, pengusaha selalu berusaha untuk meningkatkan produksi agar mencapai keuntungan maksimun dan secara agregat mampu menutup kerugian di proses sebelumnya.

Harga jual berbeda-beda dan berdasarkan penetapan harga jual yang dilakukan oleh perusahaan mitra dan negosiasi yang dilakukan oleh pemerintah dan asosiasi terkait. Selain itu faktor cuaca memengaruhi jumlah dan kualitas produk sehingga akan berdampak pada volume produksi. Disini berlaku hukum ekonomi, ketika penawaran produk meningkat sedangkan jumlah pembelian tetap maka akan terjadi penurunan harga.

Penerapan $A B C$ membantu pengusaha mengambil keputusan untuk menentukan tahap proses produksi yang digunakan, meningkatkan frekuensi produksi yang memberikan keuntungan maksimun. Perlu diperhatikan bahwa perusahaan mitra memiliki ketentuan kuota pembelian produk. Jadi 
pengusaha akan memperhatikan peringatan penutupan gudang pembelian untuk berhenti berproduksi.

\section{SIMPULAN}

Produksi pengeringan tembakau Virginia merupakan usaha yang menguntungkan. Analisis $A B C$ membantu pengusaha mengidentifikasi tahapan produksi yang memberi nilai tambah atau tidak menguntungkan bagi pengusaha. Pengusaha dapat meningkatkan produksi pada batch 3 dan seterusnya karena memberikan keuntungan yang optimal.

Keterbatasan penelitian ini hanya melihat data yang ada di lapangan dari perspektif petani/pengusaha pengeringan tembakau. Penelitian selanjutnya bisa dilakukan dengan menyandingkan antara data dari pengusaha pengeringan dan perusahaan pembeli. Harga pembelian dalam penelitian ini menggunakan harga rerata, jadi penelitian selanjutnya dapat mencari harga dari setiap perusahaan mitra. Sehingga petani/pengusaha pengeringan tembakau dapat memilih dan menentukan perusahaan yang membeli dengan harga yang paling tinggi.

\section{DAFTAR PUSTAKA}

319-20452-1-PB.pdf. (n.d.).

Djaja, G. (2001). POKOK PERMASALAHAN DALAM USAHA PENGEMBANGAN ITV DI LOMBOK - NTB PENDAHULUAN Pengelola. November.

Haque, Z. 2006. Strategic Management Accounting. Australia: Pearson

Kaplan, R. S. (2009). Time-Driven Activity-Based Costing. 1-9.

Kaplan, R. S., \& Anderson, S. R. (1990). Time-Driven Activity- Based Costing Time-Driven Activity- Based Costing. Hall Johnson and Turney 
Ed"Measuring Up Charting Pathway to Manufacturing Excellence" Business One Irwin Illinois.

http://www.sas.com/resources/whitepaper/wp_5073.pdf

Murdiyati, A. S., \& Basuki, T. (2011). Agribisnis tembakau virginia. Monograf Balittas: Tembakau Virginia. Balai Penelitian Tanaman Tembakau Dan Serat. ISBN, 978-979.

Nur, Y. H. (Kementerian P., \& Salim, Z. (Lembaga I. P. I. (2014). Nilai the Competitiveness of Local Virginia Tobacco: a Value. Jurnal Ekonomi Dan Pembangunan, 22, 1-10.

Tirtosastro, S., \& Iskandar, T. (2011). Revitalisasi kemitraan tembakau virginia di jawa timur. 11(1), 55-64. https://jurnal.unitri.ac.id/index.php/buanasains/article/view/179/180\%0 A

pengembangan-dan-penyebaran-tembakau-virginia-di-Indonesia.pdf. (n.d.).

https://www.investasi-perizinan.ntbprov.go.id/2019/08/20produksi-

tembakau berpotensi tembus 50.000 ton. Di akses tanggal 10 Maret 2020 http://distan.lomboktimurkab.go.id/bacaberita-161-budidaya-tembakauvirginia.html. Di akses tanggal 20 Februari 2020.

https://dutaselaparang.com/ekonomi/harga anjlok petani tembakau virginia gigit jari. Di akses tanggal 6 Maret 2020 